Vasvári, Louise O. "Selected English-Language Bibliography of Interest for Hungarian Cultural Studies: 20142015." Hungarian Cultural Studies. e-Journal of the American Hungarian Educators Association, Volume 8 (2015): http://ahea.pitt.edu DOI: 10.5195/ahea.2015.193

\title{
Selected English-Language Bibliography of Interest for Hungarian Cultural Studies: 2014-2015
}

\section{Louise O. Vasvári}

\begin{abstract}
As the above title indicates, because of the publication schedule of Hungarian Cultural Studies this bibliography straddles 2014-2015, covering the period since the publication in the fall of 2014 of last year's bibliography in this journal. Each year's bibliography is supplemented by earlier items, which were only retrieved recently. Although this bibliography series can only concentrate on English-language items, occasional items of particular interest in other languages may be included.

For a more extensive bibliography of Hungarian Studies from about 2000 to 2010, for which this is a continuing update, see Louise O. Vasvári, Steven Tötösy de Zepetnek, and Carlo Salzani. "Bibliography for Work in Hungarian Studies as Comparative Central European Studies.” CLCWeb: Comparative Literature and Culture (Library) (2011): http://docs.lib.purdue.edu/clcweblibrary/hungarianstudiesbibliography.
\end{abstract}

Biography: Louise O. Vasvári, who received her M.A. and Ph.D. at the University of California in Berkeley, is Professor Emerita of Comparative Literature and of Linguistics at Stony Brook University. She has also taught in various visiting capacities, including at the University of California, Berkeley, at the Eötvös Loránd University and at the Central European University in Budapest, the University of Connecticut (Storrs), and the Université de Jules Verne (Amiens). Currently she teaches one course yearly in the linguistics department at New York University and is also Affiliated Professor in American and English Studies at the University of Szeged, Hungary. She works in medieval studies, historical and socio-linguistics, translation theory, Holocaust studies, and Hungarian Studies, all informed by gender theory within a broader framework of comparative cultural studies.

Akçali, Emel and Umut Korkut. 2015. "Urban Transformation in Istanbul and Budapest: Neoliberal Governmentality in the EU's Semi-Periphery and Its Limits." Political Geography 46: 76-88.

Albert, Samuel D. "Sándor Bortnyik and an Interwar Hungarian Children's Book. 2015." Childrens' Literature and the Avant Garde. Eds. Elina Druker and Bettina KümmerlingTeilbauer. Amsterdam: John Benjamins: 65-88.

Barna, Ildikó and Andrea Pető. 2015. Political Justice in Budapest After World War II. Budapest: CEU P.

Bartha, Eszter. 2014. "The Workers' State: Industrial Labor and the Making of Socialist Hungary, 1944-1958.” Social History 39.1: 134-136. 
Vasvári, Louise O. "Selected English-Language Bibliography of Interest for Hungarian Cultural Studies: 2014-

2015." Hungarian Cultural Studies. e-Journal of the American Hungarian Educators Association, Volume 8 (2015): http://ahea.pitt.edu DOI: 10.5195/ahea.2015.193

Biró, Ákos. 2014. "Jewish Military Chaplains in the Austro-Hungarian Armed Forces During World War I.” Acta Hungarica Ethnographica 59.2: 397-406.

Borgos, Anna. 2015. “Secret Years. Hungarian Lesbian Herstories, 1950s-2000s.” Aspasia 9: 87112.

Bucur, Maria. 2015. "War and Regeneration: The Great War and Eugenics in Eastern Europe." Region 4.1: 31-43.

Cserpes, Tünde and István M. Szíjártó. 2014. "An Open Elite in Hungary? High Office Holders in the Eighteen Century.” Journal of Social History 48.1: 156-174.

Creet, Julia. 2013. "The House of Terror and the Hungarian Memorial Centre. Resentment and Melancholia in Post-89 Hungary.” European Studies 30: 29-62.

Dányi, Endre. 2013. "Democracy in Ruins: The Case of the Hungarian Parliament." The Inhabited Ruins of Central Europe: Re-Imagining Space, History and Memory. Eds.Dariusz Gafijczuk and Derek Sayer. New York: Palgrave: 55-781.

Deák, Viktória Hedvig. 2014. "Beguines in Hungary? The Case of St. Margareta of Hungary (1242-71): A Mystic Without a Voice.” Mulieres Religiosae: Shaping Female Spiritual Authority in the Medieval and Early Modern Periods. Eds. Veerle Fraeters and Imke De Gier. Turnhout: Brepols: 87-108.

Dobos, István. 2014. "Discourse Formations in Readings of the Szinbád Narratives." Hungarian Studies 28.2: 305-314.

Egri, Gábor. 2014. "National Interactions: Hungarians as Minorities and Changes in Definition of Who Is Hungarian in the 1930s." Influences, Pressures Pro and Con, and Opportunities. Studies on Political Interactions in and Involving Hungary in the Twentieth Century. Eds. Zoltán Ripp and Judit Borus. Budapest: Napvilág Kiadó: 75-98.

Farkas, Tamás. 2014. "Unconventional Anthroponyms in the Hungarian Surname System." Unconventional Anthroponyms: Function Patterns and Discursive Function. Ed. Oliviu Felecan and Daiana Felecan. Newcastle: Cambridge Scholars: 108-121.

Fazekas (Gál), Noemi. 2014. "Language Cultivation and the Concept of Linguistic Vitality in "Keleti Ujság." Identities in Literature, Discourse and MulticulturalDialogue. Ed. Julian Boldea. Targu Mures: Ahipeleg: 356-364 http://www.upm.ro/ldmd/LDMD-02/Lds/Lds\%2002\%2048.pdf

Fodor, Éva and Erika Kispéter. 2014. "Making the 'Reserve Army' Invisible: Lengthy Parental Leave and Women's Economic Marginalization in Hungary." European Journal of Women's Studies 21.4: 382-298. 
Vasvári, Louise O. "Selected English-Language Bibliography of Interest for Hungarian Cultural Studies: 2014-

2015." Hungarian Cultural Studies. e-Journal of the American Hungarian Educators Association, Volume 8 (2015): http://ahea.pitt.edu DOI: 10.5195/ahea.2015.193

Frojmovics, Kinga. 2015. "The First World War in the Hungarian Israel (Magyar Izrael), the Monthly Journal of the National Rabbinical Association, 1914-1918." European Judaism 48.1: 110-115.

Gantner, Eszter B. 2014. "Interpreting the Jewish Quarter." Anthropological Journal of European Cultures 23.2: 26-42.

Greene, Beth. 2014. "Selling Market Socialism: Hungary in the 1960s." Slavic Review 73.1: 108132.

Hatos, Pál and Attila Novák, eds. 2013.Between Minority and Majority. Hungarian and Jewish/Israeli Ethnical Experiences in Recent Centuries. Budapest: Balassi Institute.

Hites, Sándor. 2014. "Always on the Run: The Vicissitudes of Realism in Hungarian Criticism." Hungarian Studies 28.2: 275-304.

Horváth, Sándor. 2015. "Life of an Agent: Re-Energizing Stalinism and Learning the Language of Collaboration after 1956 in Hungary." Hungarian Historical Review 4.1: 56-81.

Horváth, Zsolt. 2014. "The Metapolitics of Reality: Documentary Films, Social Science Research and Cognitive Realism in Twentieth-Century Hungary." Hungarian Historical Review 3.2: 312-336.

Imre, Anikó. 2008. "Roma Music and Transnational Homelessness.” Third Text 22.3: 325-336.

Keren-Kratz, Menachem. 2015. "Maramaros, Hungary - The Cradle of Extreme Orthodoxy." Modern Judaism 35.2: 147-174.

Klímo, Árpád von. 2015. “The Cardinal Mindszenty Files from American Archives.” The Catholic Historical Review 101.2: 342-347.

Konrád, Miklós. 2014. "The Social Integration of the Jewish Upper Bourgeoisie in the Hungarian Traditional Elites.” Hungarian Historical Review 3.4: 818-849.

Kornai, János. 2015. "Hungary’s U-Turn: Retreating from Democracy.” Journal of Democracy 26.3: $34-48$.

Kosnica, Ivan. 2015. "Hungarians and Citizenship in Croatia-Slavonia 1868-1918." Athens Institute for Education and Research ATINER. ATINER's Conference Series: Law 2014-1355.

Kovács, Éva, András Lenárt and Anna Lujza Szász. 2014. “Oral History Collections on the Holocaust in Hungary." SIMON-Shoah Intervention. Methods, Documentation. Vienna Wiesenthal Institute for Holocaust Studies (VWI) http://simon.vwi.ac.at/index.php/workingpapers/43-kovacs-eva-lenart-andras-szasz-anna-lujza 
Vasvári, Louise O. "Selected English-Language Bibliography of Interest for Hungarian Cultural Studies: 20142015." Hungarian Cultural Studies. e-Journal of the American Hungarian Educators Association, Volume 8 (2015): http://ahea.pitt.edu DOI: 10.5195/ahea.2015.193

Kőváry, Zoltán. 2013. "Matricide and Creativity: The Case of Two Hungarian Cousin-Writers from the Perspective of Contemporary Psychobiography." The International Journal of Creativity and Problem Solving 23.1: 103-118.

Kürti, László. 2013. "Cold War Happiness. Singing Pioneers, Internal Enemies and Hungarian Life Under Stalin." De-Centering Cold War History. Local and Global Change. Eds. Jadwiga E. Pieper-Mooney and Fabio Lanza. London: Routledge: 75-98.

Kürti, László. 2014. “'The Women-Flogger, General Hyena:' Images of Julius Jacob von Haynau (1786-1853), Enforcer of Imperial Austria.” International Journal of Comic Art Fall/Winter: 65-90.

Koźuchowski, Adam. 2013. The Afterlife of Austria-Hungary: The Image of the Habsburg Monarchy in Interwar Europe. Pittsburgh: U of Pittsburgh P.

Kusz, Veronika. 2014. "A Wayfaring Stranger in the New World: Ernst Von Dohnányi’s American Rhapsody." American Music 32.2: 201-222.

Laczó, Ferenc. 2015. "The Foundational Dilemma of Jenö Lévai. On the Birth of Hungarian Holocaust Historiography in the 1940s." Holocaust Studies 21.2: 1-27.

. 2014. "Jewish Questions and the Contested Nation. An Analysis of Major Hungarian Debates in the Nineteenth Century." Journal of Modern Jewish Studies 3: 422-441.f . 2013. "Breaking the Silence Again. Hungarian Jewish Witness Accounts of the Nazi Camps from 1945-46." Hungarian Historical Review 2.3: 605-638.

Manchin, Anna. 2014. "Gyula Kabos and 'Jewish Difference:' Reconstructing Interwar Jewish History Through Film” Hungarian Quarterly 54.209: 172-190.

.2013. "Cabaret Comedy and the Taboo of Jewishness in Twentieth-Century Hungary.” Comedy Studies 4.2: 167-178.

Mayes, Catherine. 2014. "Eastern European National Music as Concept and Commodity at the Turn of the Nineteenth Century." Music and Letters 95.1: 70-91.

Maxwell, Alexander. 2015. “The Nation as a Gentleman's Agreement: Masculinity and Nationality in Nineteenth-Century Hungary," Men and Masculinities 18: 1-23.

Maxwell, Alexander. 2015. “The Handsome Man with Hungarian Moustache and Beard': National Moustaches in Habsburg Hungary," Journal of Cultural and Social History 12. 1: 5176.

Maxwell, Alexander. 2014. "National Wine in Hungary's Reform Era: Wine, Spirits, and the Patriotic Imagination," Central Europe 12.2: 117-35. 
Vasvári, Louise O. "Selected English-Language Bibliography of Interest for Hungarian Cultural Studies: 2014-

2015." Hungarian Cultural Studies. e-Journal of the American Hungarian Educators Association, Volume 8 (2015): http://ahea.pitt.edu DOI: 10.5195/ahea.2015.193

Montgomery, Kathleen A. 2015. "Women's Resistance to the Radical Right: Lessons from PostCommunist Hungary." Patterns of Prejudice 49.3: 225-248.

Nagy, Imola Katalin. 2014. "Transylvanianism as Identity Discourse.” Acta Universitatis Sapientiae Philologica 6.3: 317-333.

Nyíri, Pál. 2014. "Training for Transnationalism: Chinese Children in Hungary.” Ethnic and Racial Studies 37.7: 1243-1263.

Obenchain, Kathryn M. et al. 2014. "Hungarian Youth in Transylvania Discuss Hybrid Notions of Civic Liberty: Making the Case for Cultural Presentation and Multilingualism." The High School Journal 98.1: 43-63.

Pappas, Takis S. 2014. "Populist Democracies: Post-Authoritarian Greece and Post-Communist Hungary." Government and Opposition 49.1: 1-23.

Petercz, Zoltán. 2014. "The Visit of the Most Popular American of the Day: Theodore Roosevelt in Hungary.” Hungarian Studies 28.2: 235-254.

Poggi, Jsotta. 2015. "The Photographic Memory and Impact of the Hungarian 1956 Uprising During the Cold War." Getty Research Journal 7: 197-206.

Réthelyi, Mari. 2014. "Hungarian Nationalism and the Origins of Neolog Judaism" Novo Religio: The Journal of Alternative and Emergent Religions 18.2: 67-82.

Rigó, Maté, 2013. "Ordinary Women and Men: Superintendents and Jews in the Budapest Yellow-Star Houses in 1944-1945." Urban History 40.1: 71-91.

Romsics, Ignác. 2015. "The Great War and the 1918-19 Revolutions as Experienced and Remembered by the Hungarian Peasantry." Region 4.2: 173-194.

Rosen, Ilana. 2014. "Matchmaking and Marriage Narratives of Israelis of Carpatho-Rusyn Origin." Folklore 59: 45-66. http://www.folklore.ee/folklore/vol59/rosen.pdf

Rosenszky, Tamás. 2015. "Traditional Hungarian Romani/Gypsy Dance and Romanian Electronic Music in Transylvania.” Acta Ethnographica Hungarica 60.1: 43-51.

Schaff, Kai A. and László J. Kulcsár. "The Demography of Race and Ethnicity in Hungary.” The International Handbook of the Demography of Race and Ethnicity. Eds. Rogelio Sáenz, David G. Embrick, and Néstor P. Rodríguez. Dodrecht: Springer: 553-574.

Scheibner, Tamás. 2015. "Building Empire through Self-Colonization: Literary Canons and Budapest as Sovietized Metropolis." Post-Colonial Europe? Essays on Post-Communist Literatures and Cultures. Eds. Dobrota Pucherová and Róbert Gáfrik. Leiden: Brill Rodopi: $215-$ 241. 
Vasvári, Louise O. "Selected English-Language Bibliography of Interest for Hungarian Cultural Studies: 20142015." Hungarian Cultural Studies. e-Journal of the American Hungarian Educators Association, Volume 8 (2015): http://ahea.pitt.edu DOI: 10.5195/ahea.2015.193

Séllei, Nóra. 2015. "Katherine Mansfield’s Early Translations and Reception in Hungary." Katherine Mansfield and Continental Europe: Connections and Influences. Eds. Janka Kascakova and Gerri Kimber. London: Palgrave Macmillan: 26-39.

Sólyom, Barbara. 2014. "The Study of Three Generational Swabian and Hungarian Marital Mobility in a Pest County Village.” Acta Ethnographica Hungarica 59.2: 271-297.

Smith, Melanie and Márta Jusztin. 2014. "Paprika: The Spice of Life in Hungary." Spices and Tourism: Destinations, Attractions and Cuisines. Ed. Lee Jolliffe. Bristol: Channel View: 53-71.

Stevans, Joy Marya. 2015. “'Im Volkston:' The Central-European Folk Influence on Vocal Art Music by Selected Austro-Hungarian Composers." Dissertation Abstracts International DAI $76: 3$.

Strausz, László. 2014. "Producing Prejudice: The Rhetoric of Discourses in and around Current Films on Roman-Hungarian Interethnic Relations." Romani Studies: Journal of the Gypsy Lore Society 24: 1-24.

Szallai, Andrea. 2014. "Ideologies of Social Differentiation Among Transylvania Gabor Roma." Acta Ethnografica Hungarica 59.1: 85-112.

Szapor, Judit. 2014. “The Women's Debating Club Of Countess Károlyi: Hungarian Women's Revolutionary and Counter-Revolutionary Activism in 1918/19." L'Homme. European Journal of Feminist History 25.2: 63-71.

Szapor, Judit.. 2014. "Private Archives and Public Lives: The Migrations of Alexander Weissberg and the Polanyi Archives," Jewish Culture and History 15. 2: 93-109.

Székely, Julia. 2013. "Hacking History in Budapest: Public Monuments as Forms of an Alternative Messaging System." International Journal of Tourism Anthropology 3.2: 184-199.

Szita, Szabolcs. 2013. "A Few Questions Regarding the Return of the Hungarian Deportées: The Example of the Mauthausen Concentration Camp." Between Minority and Majority. Hungarian and Jewish/Israeli Ethnical Experiences in Recent Centuries. Eds. Pál Hatos and Attila Novák. Budapest: Balassi Institute: 111-121.

Takács, Judit. 2015. "Disciplining Gender and (Homo)sexuality in State Socialist Hungary in the 1970s." European Review of History: Revue européenne d'histoire 22.1: 161-175.

Takács, Tibor. 2015. "Them and Us: Narratives of Agents from the Kádár Era." Hungarian Historical Review 4.1: 144-170.

Timár, Judit and Éva G. Fekete. 2010. "Fighting for Recognition: Feminist Geography in East Central Europe." Gender, Place and Culture 17: 775-790. 
Vasvári, Louise O. "Selected English-Language Bibliography of Interest for Hungarian Cultural Studies: 2014-

2015." Hungarian Cultural Studies. e-Journal of the American Hungarian Educators Association, Volume 8 (2015): http://ahea.pitt.edu DOI: 10.5195/ahea.2015.193

Tóth-Czifra, Erzsébet. 2014. "From Cabernet Sauvignon to Egri Csillag: Changing Patterns in Hungarian Wine Naming." Hungarian Studies 28.2: 315-332.

Varga, Bálint. 2014. “Multilingualism in Urban Hungary, 1880-1910.” Nationalities Papers 42.6: $965-980$.

Varga, Mihai. 2014. "Hungary's 'Anti-Capitalist' Far-Right: Jobbik and the Hungarian Guard." Nationalities Papers 42.5: 791-807.

Vasvári, Louise O. 2015. "Hungarian: Gender Trouble in a Grammatically Genderless Language." Gender Across Languages 4. Eds. Marlis Hellinger and Heiko Motschenbacher. Amsterdam: John Benjamins: 201-223.

Veszprémi, Nóra. 2014. "The Emptiness Behind the Mask: The Second Rococo in Painting in Austria and Hungary." The Art Bulletin 96.4: 441-462.

Zadányi, Edit. 2015. "Viewing the Subaltern by Narrating the Communist Past through the Focalization of the Child in Gábor Németh's 'Are you a Jew?' and Endre Kukorelly's 'The Fairy Valley'." Post-Colonial Europe: Essays on Post-Communist Literatures and Cultures. Eds. Dobrota Pucherová and Róbert Gáfrik. Leiden: Brill Rodopi: 175-196.

Zipernovszky, Kornél. 2014. “'Who Will Win the Jazz or Gypsy, It Is Hard to Tell': Gypsy Musicians Defend Hungarian National Culture." Americana: E-Journal of American Studies in Hungary 10 [no pagination] http://americanaejournal.hu/vol10jazz/zipernovszky

Zupka, Dusan. 2014. "Communication in a Town: Urban Rituals and Literacy in the Medieval Kingdom of Hungary." Uses of the Written Word in Medieval Towns: Medieval Urban Liteary II. Tornhout: Brepols: 341-373. 